\section{Perceptions of Value}

In 1969, authors of The Behavioral and Social Sciences: Outlook and Needs, a joint report of the National Academy of Sciences and the Social Science Research Council, observed, "The rate of growth of the behavioral and social sciences will depend on the wisdom and foresight with which they are organized and funded, but whatever the temporary perturbations, these disciplines will continue to develop both as sciences in their own right and as aids in the handling of social problems" (261). This issue of PS examines the public value of political science research, demonstrating that over the course of the past 30 years political science as a discipline has continued to develop as a science as predicted and has contributed in significant ways to our collective understanding of human behavior and institutions.

It is unfortunate that contributions of political science research often go unrecognized, or, worse yet, are denigrated as little more than conventional wisdom rewritten in an esoteric vocabulary. The reason for this misunderstanding is not hard to find, according to the authors of the NAS/SSRC report. Political science, like the other social sciences, addresses complex social behavior and problems to which policymakers and the public would like simple explanations and ready solutions. When neither is forthcoming from political scientists, policymakers discount the value of the research done and oppose increasing public investment in political science research.

As the articles in this issue of $P S$ clearly demonstrate, political scientists have been investigating behavior and institutions in international and domestic settings, closely examining how and why nations, communities, and individual citizens respond to the changing worlds in which they live. As articulated by the symposium authors, these studies are not merely academic exercises; they have broad social applicability and value.

In recent years, the political science program of the National Science Foundation has received only token increases while other disciplines have been generously rewarded for their reputed contributions and alleged intellectual excitement. There are new possibilities for change, however.

Addressing an audience at the California Institute of Technology on January 21, 2000, President Clinton first announced his intention to ask Congress to approve a $\$ 2.8$ billion increase in federal research funds. The National Science Foundation would, under the Clinton plan, receive an additional $\$ 675$ million for Fiscal Year 2000 , the largest dollar increase in its 50 year history. There are signs from within the National Science Foundation that the budget of the political science program may increase significantly.

However, the budget of the traditional political science research program will probably not expand markedly. The National Science Foundation is likely to focus new

\section{Symposium Contributors}

Henry E. Brady is professor of political science and public policy and director of the Survey Research Center at the University of California, Berkeley. He has done survey research on politics and public policy in Canada, Estonia, Russia, and the United States. He is the coauthor, with Sidney Verba and Kay Schlozman, of Voice and Equality: Civic Voluntarism in American Politics (Harvard University Press, 1995).

Alexander L. George is Graham H. Stuart Professor Emeritus of International Relations at Stanford University. A specialist on deterrence, crisis prevention and management, and coercive diplomacy, George worked at the Rand Corporation from 1948 to 1968. His books include Limits of Coercive Diplomacy (1994) and Bridging the Gap: Theory and Practice of Foreign Policy (1993).

Michael Laver is head of the department of political science at Trinity College Dublin and director of the university's Policy Institute. He has written extensively on government formation and duration and rational choice theory. His books include Making and Breaking Governments (1996), and Playing Politics: The Nightmare Continues (1997).

Arthur Lupia is professor of political science at the University of California, San Diego. He is coauthor of The Democratic Dilemma: Can Citizens Learn What They Need to Know? (1998) and Stealing the Initiative: How State Government Reacts to Direct Democracy (2000), and is coeditor of Elements of Reason: Cognition, Choice, and the Bounds of Rationality (2000). He received the National Academy of Science's Initiatives in Research Award in 1998.

Michael C. Munger is associate professor of political science at Duke University. His current research interests include the ideology of racism in the slave South and the disposal of low-level radioactive waste. His most recent book is Policy Analysis: Conflict Between Experts and Democracy (W.W. Norton, 2000)

Elinor Ostrom is the Arthur F. Bentley Professor of Government in the department of political science at Indiana University. She is also co-director (with Vincent Ostrom) of the Workshop in Political Theory and Policy Analysis and co-director (with Emilio Moran) of the Center for the Study of Institutions, Population, and Environmental Change at IU.

Randolph M. Siverson is professor of political science at the University of California, Davis. He is the coauthor of The Diffusion of War (1991) and the editor of Strategic Politicians, Institutions and Foreign Policy (1998). His articles have appeared in the American Political Science Review, the American Journal of Political Science and the Journal of Conflict Resolution. 
spending on broad, interdisciplinary initiatives encompassing such areas as nanotechnology, biocomplexity, and information technology. The relevance of these research arenas to political science remains an open question and a challenge for the discipline. Whatever the level of funding, NSF's programmatic spending will be affected by the perceived public value of political science research. The conventional measure of the public value of a science and technology is its contribution to economic growth and public health. Since political science research will likely never spawn a new generation of dot coms nor increase longevity, a finer instrument is needed to appreciate its value. This symposium, so expertly gathered and introduced by Skip Lupia, clearly affirms the public value of political science research and provides ample justification for continued and expanded public and private investment

Further justification for the need for continued and expanded investment in social science research echoes through the president's concluding remarks at $\mathrm{Cal}$ Tech.

Observing that genomic research has confirmed that the peoples of the world are $99.9 \%$ genetically the same, Clinton concluded that the supreme irony of our time is that "the biggest social problem is the oldest demon of human society-we are still afraid of people who aren't like us. And fear leads to distrust, and distrust leads to dehumanization, and dehumanization leads to violence." The dynamics of human social and political behavior and the institutional arrangements within which this behavior takes place is the stuff of political science and its sister disciplines. That mankind is still beset by old demons is argument enough for expanding the search among the social sciences for explanations and solutions.

RJPH

\section{Attention Current and Recent Doctoral Students}

Ever wonder how your graduate school experience compares to those of others? Curious which political science department has the best faculty mentoring? The worst career guidance? So are we. The National Association of Graduate-Professional Students (NAGPS) is conducting "The National Doctoral Program Survey" (http:// survey.nagps.org/l, a department-by-department assessment of educational and professional development practices and graduate student satisfaction in all academic fields, including political science. The survey is funded by a grant from the Alfred P. Sloan Foundation and is being supported by over 50 professional societies, including the APSA.

The survey will compile the experiences of doctoral students, present and past lany time within the last five years/, on a department-specific basis to determine which programs are doing a great job of educating and preparing Ph.D.s - and which need to improve. Rankings and results of individual programs will be publicly available on the Internet by Fall 2000.

Go to the survey web site (http://survey.nagps.org/) before June 1, 2000, to complete the survey. A significant percentage of students must respond for the results to represent a broad range of experiences and produce a realistic picture of department and institutional practices. A high response rate is essential, so every current and recent doctoral student should fill it out. Encourage all your friends and colleagues to complete the survey as well. This is your opportunity to open the doors to your department and to praise or pan local practices. Completing the survey only takes a few minutes but can stimulate change in graduate education for years to come. 


\section{PROCEEDINGS}

\section{POLITICAL RESEARCH ONLINE}

\section{What is PROceedings?}

PROceedings is the online, searchable collection of APSA Annual Meeting papers and abstracts.

How does it work?

mission is simple: papers can be sub-

The PROceedings project aims to disseminate political science research more broadly and directly, to continue the scholarly exchange of the annual meetings beyond their setting, to encourage the instructional use of research and to facilitate individual and library access to the annual meeting papers.

PROceedings, a collaborative effort of APSA, Harvard University Library, and The College of New Jersey under the direction of William J. Ball, was introduced at the 1997 Annual Meeting and is supported by a grant from the Andrew W. Mellon Foundation.

All annual meeting paper authors are encouraged to submit their papers to the collection prior to the Annual Meeting. Submitted online, via email, or on disk. Authors can begin submit -ting papers in early July.

Papers are made available two weeks prior to the annual meeting and remain online for one full year.

Papers can be located through keyword searches or by browsing the APSA Annual Meeting program. The collection features numerous subfields of political science, making it a valuable resource for research and teaching.

\section{More than 1,000 papers from APSA's 1999 Annual Meeting are} now online.

\section{http://pro.harvard.edu}

Annual Meeting paper authors will receive detailed instructions about participating in PROceedings in May 2000. If you have questions about, or suggestions for, PROceedings, please write to proceedings@apsanet.org. 


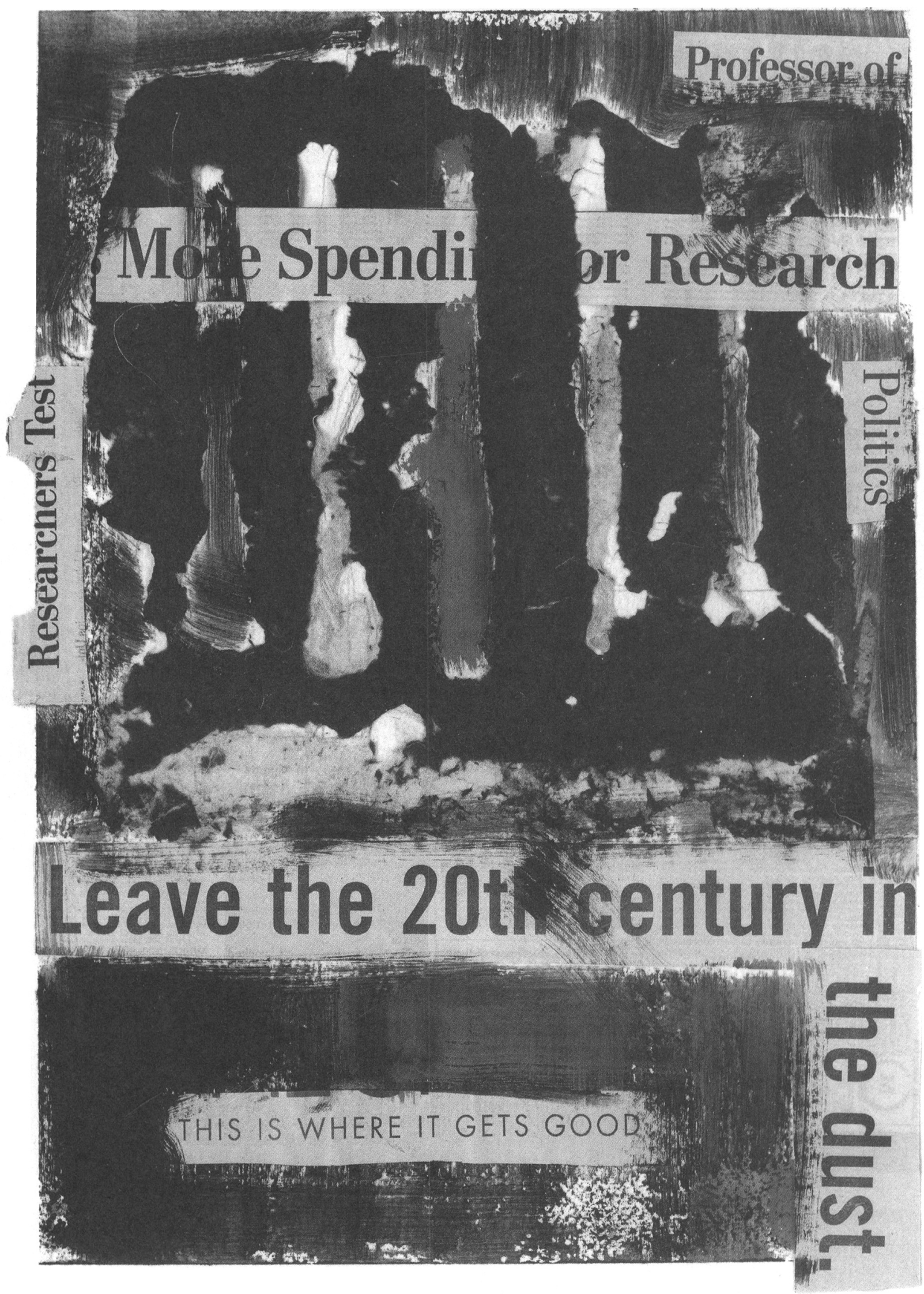

RJPH, Headlines \#2, mixed media 